\title{
Isolation and Economic Life in Eighteenth-Century France
}

\section{Citation}

Rothschild, Emma. 2014. "Isolation and Economic Life in Eighteenth-Century France." The American Historical Review 119 (4) (October): 1055-1082. doi:10.1093/ahr/119.4.1055.

\section{Published Version}

doi:10.1093/ahr/119.4.1055

\section{Permanent link}

http://nrs.harvard.edu/urn-3:HUL.InstRepos:34334612

\section{Terms of Use}

This article was downloaded from Harvard University's DASH repository, and is made available under the terms and conditions applicable to Open Access Policy Articles, as set forth at http:// nrs.harvard.edu/urn-3:HUL.InstRepos:dash.current.terms-of-use\#OAP

\section{Share Your Story}

The Harvard community has made this article openly available.

Please share how this access benefits you. Submit a story.

Accessibility 


\section{ISOLATION AND ECONOMIC LIFE IN EIGHTEENTH-CENTURY FRANCE1}

The history of France in the world is now newly and brilliantly transnational. ${ }^{2}$ It is also disconnected, for the most part, from the largest stories of national destiny. ${ }^{3}$ There are two Frances, in an enduring understanding: a real France, or "la France profonde," of the majority of individuals who lived local, small-scale and immobile lives; and a France of the superficial or fluctuating

\footnotetext{
1 I am grateful to the staff of the Archives Municipales d'Angoulême and the Archives Départementales de la Charente, to Sunil Amrith, Keith Baker, Benjamin Golub, Victoria Gray, Ian Kumekawa and David Todd for many illuminating comments and conversations, to Robert A. Schneider, to Ian Kumekawa, Amy Price and Madeleine Schwartz for collaboration in collecting and visualizing information about Angoulême, and to the Joint Center for History and Economics for an inspiring research environment.

2. On "'global' history in the true sense of the word," in which "a civilization, by its essence, is an international fact," see Lucien Febvre and François Crouzet, Nous sommes des sang-melés: Manuel d'histoire de la civilisation française (1950) (Paris, 2012), ed. Denis and Elisabeth Crouzet, 18, 24; and see Marc Bloch and Lucien Febvre, "La documentation de l'histoire économique: Nos enquêtes collectives," Annales d'histoire économique et sociale 1, no. 1 (1929): 58-59. Among important early studies of migration, colonial administration and slave society, see Gabriel Debien, Les engagés pour les Antilles (1634-1715) (Paris, 1952), Gabriel Debien, Plantations et esclaves à Saint-Domingue (Dakar, 1962), Jean Tarrade, Le commerce colonial de la France à la fin de l'ancien régime: L'évolution du régime de 'l'Exclusif' de 1763 à 1789 (Paris, 1972), and Jean Mettas, Répertoire des expéditions négrières françaises au XVIIIe siècle, ed. Serge and Michèle Daget, 2 vols. (Paris, 1978-1984). On the "new" global history of France, see Stephen W. Sawyer, "Ces nations façonnées par les empires et la globalisation," trans. Aurore Clavier, Annales. Histoire, Sciences Sociales 69, no. 1 (2014): 117137; Alain Cabantous, "Résistance de principe ou lucidité intellectuelle? Les historiens français et l'histoire atlantique," Revue historique 663 (2012): 705-726; Silvia Marzagalli, "Le négoce maritime et la rupture révolutionnaire: un ancien débat revisité," Annales historiques de la Révolution française, 352 (2008): 184-207; and Caroline Douki and Philippe Minard, "Histoire globale, histoires connectées: un changement d'échelle historiographique? Introduction," Revue d'histoire moderne et contemporaine 54, no. 4bis (2007), 7-22.
}

3. Studies which connect long-distance and national histories include, on mobility within France, Daniel Roche, Humeurs vagabondes: de la circulation des hommes et de l'utilité des voyages (Paris, 2003), on the transnational and local history of northern France, Renaud Morieux, Une mer pour deux royaumes: la Manche, frontière franco-anglaise (XVIIe-XVIIIe siècles) (Rennes, 2008), and on economic growth, Guillaume Daudin, Commerce et prosperité: la France au XVIIIe siècle (Paris, 2005.) 
periphery, of ports, frontiers and foreign influences. ${ }^{4}$

It is this assumption, of the unimportance of outside events to real or interior or national histories, that can be called into question in a history of economic life in the French provinces in the eighteenth century. The history of social, domestic and economic information, in particular, can provide a different view of the influence of long-distance connections in the interior provinces of France. This history of economic life is a story of the lives of individuals who lived amidst exchanges of information and expectations, more than of "how the economy evolves." ${ }^{5}$ It is inspired by the microeconomics of individuals and their social networks, rather than by the macroeconomics of national or global flows of commodities. ${ }^{6}$ It is a return to the sources, and even to the "project,"

4. The two Frances corresponded, in turn, to two kinds of history, light and dark, glittering and obscure, changing and immobile, eventful and eventless. Fernand Braudel, Écrits sur l'histoire (Paris, 1969), 21-24, 62-64, 114. On "l'indifférence de la France profonde" to the outside world, see "L'Ancien Régime et la mer," in Pierre Goubert and Daniel Roche, Les Français et L'Ancien Régime, 1. La société et l'état (Paris, 1984), 328. The "two economies living side by side, under different laws" were described by Herbert Lüthy, La Banque Protestante en France de la Révocation de l'Edit de Nantes à la Révolution, 2 vols. (Paris, 1961), 2: 24-25. In an even starker depiction of the "two Frances," the historical geographer Edward Whiting Fox proposed the "hypothesis of two separate and independent societies, one commercial, the other agricultural," with "an entirely different system of communication," a "discrete social structure," and distinctive political cultures. Edward Whiting Fox, History in Geographic Perspective: The Other France (New York, 1971), 14, 37, 61, 182. The implication of such distinctions, as François Crouzet wrote in 1966, was that the expansion of French external commerce in the eighteenth century "was a purely superficial, epidermic phenomenon, of little real importance for the national economy." François Crouzet, "Angleterre et France au XVIIIe siècle: essai d'analyse comparée de deux croissances économiques," Annales. Économies, Sociétés, Civilisations 21, no. 2 (March-April 1966): 254-291, 265, 265, n.2.

5. Naomi R. Lamoreaux, "Rethinking Microhistory: A Comment," Journal of the Early Republic 26 (Winter 2006): 555-561, 560. On social and political histories of economic life, see William H. Sewell, Jr., "A Strange Career: The Historical Study of Economic Life," History and Theory 49, no. 4 (December 2010): 146-166, and Jeremy Adelman, Republic of Capital: Buenos Aires and the Legal Transformation of the Atlantic World (Stanford, 1999).

6. On the microeconomics of development, see Abhijit Banerjee and Esther Duflo, Poor Economics: A Radical Rethinking of the Way to Fight Global Poverty (New York, 2011). On social network theory, see Benjamin Golub and Matthew O. Jackson, "How Homophily Affects the Speed of Learning and Best-Response Dynamics," Quarterly Journal of Economics 127, no. 3 (August 2012): 1287-1338 and Matthew O. Jackson, Tomas Rodriguez-Barraquer, and Xu Tan, 
of social history. ${ }^{7}$ It is also the outline of a history which can start, like the microeconomics of development, with "the economic lives of the poor," and move outwards: from individuals, and their local circumstances, to larger connections, including the individuals' own connections and discontinuities. ${ }^{8}$

The "impact" or "influence" of "the Atlantic economy... on eighteenth-century France" is a "major and underresearched question," as Laurent Dubois has written. ${ }^{9}$ But impact or influence is the outcome both of economic exchanges and of what the exchanges meant; of multiple economic and social connections, including "personal influence," in the sense of the exchange of information and "intermediation," or the communication of opinions across different individuals. ${ }^{10}$ It is these exchanges that are the subject of this essay, in relation to the impact of the larger outside world -- or the world beyond the geographical France -- in the small provincial town of Angoulême, within one of the most isolated provinces of the center of France, the old generality of Limoges. ${ }^{11}$

"Social Capital and Social Quilts: Network Patterns of Favor Exchange," American Economic Review 102, no. 5 (August 2012): 1857-1897.

7. "'Social" history" was "a project and a way of seeing," Pierre Goubert wrote in 1960; "like so many others, I simply felt the desire and almost the need to interest myself in all men, and not only in those who shone because of their birth, their standing, their role, their wealth, or their intelligence." Pierre Goubert, Beauvais et le Beauvaisis de 1600 à 1730: contribution à l'histoire sociale de la France du XVIIe siècle (Paris, 1760), vii.

8. Banerjee and Duflo, Poor Economics, x. On "inductive" history, see AHR Editor, "Comment," in "AHR Conversation: How Size Matters: The Question of Scale in History," American Historical Review 118, no. 5 (December, 2013): 1431-1472, 1459.

9. Laurent Dubois, “An Atlantic Revolution,” French Historical Studies 32, no. 4 (Fall 2009): 655-661, 659-650; David A. Bell, "Questioning the Global Turn: The Case of the French Revolution,” French Historical Studies 37, 1 (Winter 2014), 1-24, 6, 19.

10. On the sociology of influence, see Elihu Katz, "Lazarsfeld's Legacy: the Power of Limited Effects," in Elihu Katz and Paul F. Lazarsfeld, Personal Influence: The Part Played by People in the Flow of Mass Communications (Piscataway, NJ, 2006), xv-xxvii. On social networks of information, see Ronald S. Burt, "Social Contagion and Innovation: Cohesion versus Structural Equivalence," The American Journal of Sociology 92, no. 6 (May 1987): 1287-1335.

11. The idea of the geographical France, "so admirably compact," was described by the agronomist Arthur Young in the odd terms of France-as-Borneo. [Arthur Young], Letters 
The generality of Limoges, which extended in the eighteenth century from the mountains of the Massif Central to Angoulême, was known at the time as an "unhappy" and impoverished region of Europe; "poor, without cultivation, without commerce, without roads, without navigation, far from the capital."12 It was an "interior" province, in the revolutionary classification of 1793, with relatively few exports. ${ }^{13}$ It was known, even, as a society of moral isolation. Angoulême was in Balzac's description a place of "the most fatal immobility." To become unprovincial, in Les illusions perdues, was to "se désangoulêmer," or to "de-Angoulêmize oneself."14

The idea of an economy was new in the 1760 s, and it was a conception of what the economist and statesman A.R.J. Turgot, who was the intendant of the generality of Limoges in 1761-1774, described as a flow or stock of things: the "total commerce of a nation," or the "totality of the wealth of a nation." ${ }^{, 15}$ But the history of long-distance connections is also a history of

concerning the Present State of the French Nation (London, 1769), 385.

12. [Mathieu François Pidanzat de Mairobert], L'Observateur Anglois, ou Correspondance secrète entre Milord All'Eye et Milord Alle'Ar, 10 vols. (London, 1777-78), 1: 297. The generality of Limoges, at the time of Turgot's administration, corresponded approximately to the modern region of the Limousin, or the departments of the Haute-Vienne, Corrèze and Creuse, together with Angoulême (the interior part of the modern region of Poitou-Charente.) On the Limousin in the period of Turgot's administration, see Gustave d'Hugues, Essai sur l'administration de Turgot dans la généralité de Limoges (Paris, 1859), and Michel C. Kiener and Jean-Claude Peyronnet, Quand Turgot régnait en Limousin: Un tremplin vers le pouvoir (Paris, 1979), and, on the nineteenth century, Alain Corbin, Archaïsme et modernité en Limousin au XIXe siècle 1845-1880: La rigidité des structures économiques, sociales et mentales (1975) (Limoges, 1998).

13. The division of France into maritime, frontier and interior provinces or "sections" was established in the revolutionary period; the value of exports per inhabitant in the generality of Limoges was estimated as 3.0 livres in 1787, compared to 12.2 livres in France as a whole, and 15.9 livres in the maritime provinces. Ambroise-Marie Arnould, De la balance du commerce, 2nd ed., 3 vols. (Paris, [1795]), 3: Tables 9,15.

14. Honoré de Balzac, Les illusions perdues (Paris, 1974), 56, 176.

15. Réflexions sur la formation et la distribution des richesses (1766), in A.R.J.Turgot, Oeuvres de Turgot et documents le concernant, ed. Gustav Schelle, 5 vols. (Paris, 1913-1923) [hereafter $O T], 2: 594,596$. On the view that the idea of the economy as "an enormous conglomeration of interdependent markets" was invented in the middle years of the eighteenth century, and was made possible by improvements in market institutions, see M.I.Finley, The Ancient Economy 
economic life in the senses of the activities of the state and of the domestic economy of families or households. It is a history, in turn, that can be seen from different perspectives, or in different resolutions: from the national to the provincial to the connections of a group of "capitalistes" (in their own self-description) who were involved in an extended legal, financial and commercial affair in Angoulême; and to the exchanges of a woman named Marie Aymard - she was the illiterate and indigent widow of a joiner who emigrated to the island of Grenada - and at her own social and information networks, within the extended families of artisans in Angoulême. ${ }^{16}$ This history of influence can provide a view, from the inside outwards, of the multiple connections between the interior of France and the outside world. It also suggests new approaches to very old historical questions; and the possibility of zooming out as well as in, from the history of individuals to a larger world of information and exchange.

"In a great State, exterior commerce constitutes a very minimal object in comparison to the interior commerce of national products," Turgot wrote in 1770, and only a small proportion of goods and services were exported in eighteenth-century France. ${ }^{17}$ In the generality of Limoges, the imports of agricultural commodities were of importance at the margin of food consumption, and in unusual circumstances. ${ }^{18}$ It was only to the south-west, in the brandy-producing country to the west of Angoulême, that cultivators produced crops in any substantial quantity for export to the outside

(London, 1975), 21-22; Eric Roll, A History of Economic Thought (London, 1973), 20, 371.

16. "Procuration par Marie Aymard," October 16, 1764, Archives Départementales de la Charente [hereafter ADC], Bernard, notary, 2E153.

17. "Lettre au Contrôleur Général," November 14, 1770, OT, 3: 289.

18. The terrible scarcity of $1769-1770$ in the generality was eventually averted, in part, because of the overseas connections of the inland commerce; a merchant from Limoges who brought corn from Danzig, another Limoges merchant with connections in Amsterdam, and a merchant in Brive, who together with associates in Bordeaux and Bremen, "had a vessel laden with rye at sea, coming from Stettin." "Compte rendu au Contrôleur général des opérations relatives à la disette de 1770 ," in $O T, 3: 450-451$. 
world, of which the principal markets included "the armies," in times of war, and in times of peace, the slaving forts of West Africa and the British, French, and Dutch colonies. ${ }^{19}$

19. It was only "our neighbours" to the south, a merchant in Brive lamented in 1766, who were able to embark "a great deal of corn which is sent to Bordeaux, or converted to flour for the colonies." "Mémoire de M. Malpeyre du Saillant fils" of 1766, to the Agricultural Society of Limoges, in Choix de documents historiques sur le Limousin, ed. Alfred Leroux (Limoges, 1891), 319-335.On the "brandy-buying hinterland of the town of Cognac" and "the rise of Angoulême as a business centre" by the 1770s, see L.M.Cullen, The Brandy Trade under the Ancien Régime Regional Specialisation in the Charente (Cambridge, 1998), 52-53 and map 2, 111; and C.-E. Labrousse, La crise de l'économie française à la fin de l'ancien régime et au debut de la révolution (Paris, 1943), 260-265. In 1775, brandy accounted for 1.2 million out of a total value of 10.5 million livres of exports of articles for the slave trade. Tarrade, Le commerce colonial, 123-125. 
Domestic, commercial, and religious services - the services that economists found so difficult to measure, and even to name - accounted for most of the non-agricultural economy. ${ }^{20}$ There were the services of servants and domestics, who accounted for about 12 percent of the adult population of Angoulême in 1764. ${ }^{21}$ There were small traders; women selling trinkets, ribbons and herbs, or renting chairs and washing clothes. ${ }^{22}$ In the towns, there were inn-keepers and surgeons and musicians and dancing masters; a "fictive model" of a register of towns in the generality in 1762 , for purposes of collecting the taille imposition, listed the inhabitants of a two-story house as a merchant, a lawyer, a wigmaker, and an attorney's clerk, together with their children and servants. ${ }^{23}$ Their services entered into overseas trade only indirectly; as "invisible" exports, like the services of the bankers and brandy merchants who were at the center of the long affair of the "capitalists."

Manufacturing was expanding in the province in the 1760s, and it was connected to longdistance exchanges of fibers, metal products, and styles of design. Turgot in 1767 described a "multiplication of manufactures," with the production of "cotonades" in Angoulême, and "spun cotton from the Levant imported through Marseille." ${ }^{24}$ One of his inspectors prepared a "catalogue"

20. The production of services was described variously as sterile, unproductive and immaterial. The public services of "war and the administration of justice," in particular, were contributed as a "personal service" by the individuals whom Turgot described as the "classe disponible" (the available or the dispensable class.) Réflexions, OT, 2: 541-542.

21. Abbé Expilly, Dictionnaire géographique, historique et politique des Gaules et de la France, 6 vols. (Paris and Amsterdam, 1762-1770), 4: 239.

22. "Cahiers de l'etat des classes faites pour la faction du role pour 1763," Archives Municipales d'Angoulême [hereafter AM-A], CC42, and "Répartition de la taille pour la classe au dessus de 10s, de subsistance," 1765, AM-A, CC62.

23. "Lettre circulaire aux officiers municipaux sur les rôles des tailles dans les villes," August 31, 1762, in Oeuvres de Mr. Turgot, Ministre d'Etat, ed. Dupont de Nemours, 9 vols. (Paris, 180811), 9: 437. The fictitious register is omitted in the later, Schelle edition of Turgot's works; $O T$, 2: 168 .

24. Memorandum of October 6, 1767, in Archives Nationales, Paris (AN), Manufactures, 1397$1786, \mathrm{~K} / 909 / 21 / 2$. 
of the "almost 1300 spinning women" in Limoges, and concluded that cotton spinning was "very extensive," with the production of "grosses siamoises," and traders who "every year export a very large quantity." ${ }^{25}$ An Almanac of merchants in 1774 listed twenty-five manufacturers in the little town of Saint-Léonard, producing casseroles, paper, and "drugget cloth for the use of the troops;" in Brive, a forgeowner was said to produce "kettles and cauldrons for America," and a manufacturer of "English" stuffs produced "indiennes" (painted or printed cloths), yellow silk gauze, and red handkerchiefs "in the style of the Indies." 26

There were foreign commodities available, to a limited extent, in the small towns of the generality. The rich bourgeoisie and new nobility left elaborate wealth to be inventoried after their deaths; a dress of Indian batiste lined in pink taffeta and a skirt of embroidered "siamoise," owned by the widow of an army officer in Angoulême; or 124 shirts in different fabrics, a dress made of Indian satin and a sixteen-volume history of England, among the effects of the 25-year-old wife of the mayor of the town, who was herself an heiress from Martinique. ${ }^{27}$ But Turgot's conclusion that "merchandise imported from abroad... makes up only a very small part of total consumption" was true of the generality as a whole, for the reason that he himself gave: it was "an object of luxury,

25. Pierre Cornuau, "Second mémoire," in Archives Départementales de la Haute-Vienne [hereafter ADH-V], C.13, undated ; on Cornuau and his dream of the "vast enterprise" of a cadastral survey, see M. Fougères [Marc Bloch], "Les plans cadastraux de l'ancien régime," Mélanges d'histoire sociale 3 (1943): 55-70, 60-61; and see Lucien Febvre, "Marc Bloch fusillé," Mélanges d'histoire sociale 6 (1944): [5]-[8].

26. Almanach général des marchands, negocians, armateurs, et fabricans de la France et de l'Europe, et autres parties du monde (Paris, 1774), unpag., entries for Brive and Saint-Léonard. On "indiennes" or painted and printed cloths, and African traders as a market for French producers of counterfeit Indian and English textiles, see Edgard Depitre, La toile peinte en France au XVIIe et au XVIIIe siècles: industrie, commerce, prohibitions (Paris, 1912), 242-258 and Pierre H. Boulle, "Marchandises de traite et développement industriel dans la France et l'Angleterre du XVIIIe siècle," Revue française d'histoire d'Outre-Mer 62 (1975): 309-330.

27. "Recollement de l'inventaire des meubles et effets de feues M. et Mme. Robuste de Frédilly," May 24, 1745, ADC, Bernard, notary, 2E134; "Inventaire des meubles, effets, titres et papiers de la communauté de M. Trémeau et de déffunte dame Gonnet son épouse," December 5-7, 1768, ADC, Caillaud, notary, 2E288. 
which is only within reach of the rich; the people consume only what they find around them, and the people everywhere make up the large majority of the population." ${ }^{28}$ The total yearly expenditure or consumption of landless peasants in the generality was estimated at less than 25-35 livres, in money and in kind; or a little less than the value of an iron frying pan, in the inventory of the mayor's wife. $^{29}$

To see the economic life of the province in relation to the state, which was the perspective of an older science of political economy, is to have a different view of the influence of the outside world. The new idea of an economy, in the 1760 s, was based on a conception of market exchanges as natural, and as essentially "economic." ${ }^{30}$ The activities of the state were in this view uneconomic; they constituted the limits of the economy, or an outside intervention in the economy, or both. But the French state was an overwhelming presence in economic relationships; the "greatest consumer of industrial products and the greatest entrepreneur of construction projects that there was in the kingdom," in Tocqueville's later description. ${ }^{31}$ Tax contributions in the generality of Limoges were estimated at 13 livres per person, in 1784, or a little less than half of the estimated yearly

28. "Lettre au Contrôleur Général," November 14, 1770, in OT, 3: 289.

29. "Mémoire au Conseil sur la surcharge des impositions" (1766), and "Lettre au Contrôleur Général," December 16, 1769, in OT, 2: 453 and 3: 113; "Inventaire des meubles de dame Gonnet," ADC, Caillaud, notary, 2E288.

30. Finley, The Ancient Economy, 21-22. In Marx's description, "a definite social relation between men" assumes "the fantastic form of a relation between things." Karl Marx, Capital, transl. Samuel Moore and Edward Aveling, 3 vols. (London, 1970), 1: 72.

31. Alexis de Tocqueville, L'ancien régime et la révolution, ed. J.-P. Mayer (Paris, 1967), 280. The fiscal-military state was in particular the "largest actor" in the "economic life" of the generality of Limoges, as it was in England in the same period. John Brewer, The Sinews of Power: War, Money and the English State, 1688-1783 (Cambridge, MA, 1988), xvii, xxi, and on the comparison of France and England, 15-21, 126-134; James C. Riley, The Seven Years War and the Old Regime in France: The Economic and Financial Toll (Princeton, 1986). 
consumption of the peasants who constituted the majority of the population. ${ }^{32}$

Taxation was connected everywhere in France to the vicissitudes of military fortune and of long-distance exchanges. Even in peacetime, the army, navy and colonies accounted for 53 percent of government expenditure, net of interest payments. ${ }^{33}$ The taille was an imposition, in its origins, for the support of the king's military forces, and its variation from year to year was a source of continuing uncertainty and oppression. ${ }^{34}$ The corvée of services in kind, to which Turgot devoted so much of his time in Limoges, was in part for the transport of troops and military equipment, and in part a service to naval contractors, in the form of river haulage on the Charente. ${ }^{35}$

The government's own expenditure changed unpredictably over time. The oak forests of the Limousin provided wood for the expansion in naval procurement, in which the navy's reserves of construction timber increased more than four-fold from 1764 to $1769 .{ }^{36}$ There were regiments which passed through the province, "impatient at the slowness of the oxen," barracks to be built for cavalry garrisons, and seizures of beds, livestock, and ploughs. ${ }^{37}$ In the west of the generality, the

32. Jacques Necker, De l'administration des finances de la France I, in Oeuvres complètes de M. Necker, ed. A.L. de Staël-Holstein, 15 vols. (Paris, 1820-1821), 4: 326.

33. The army, navy and colonies accounted for an estimated 28 percent of all government expenditure in the peacetime year of 1784 , and 53 percent of government expenditure excluding interest payments, debt reimbursement, and the costs of collecting taxes. De l'administration des finances de la France II, in Necker, Oeuvres Complètes, 5: 142-158, 190, 231-232.

34. "Lettre au Contrôleur Général," October 30, 1761, in OT, 2: 97-99.

35. One of Turgot's first letters as minister of the navy was to the intendant of Tours, on July 30 , 1774, to say that he had never approved these services in Limoges, and that they were not required in Tours. Alexis de Tocqueville, L'ancien régime et la révolution: fragments et notes inédites sur la révolution, ed. André Jardin (Paris, 1953), 378-379.

36. Martine Acerra, Rochefort et la construction navale française, 1661-1815, 4 vols. (Paris, 1993), 2: 250; T.J.A. Le Goff and Jean Meyer, "Les constructions navales en France pendant la seconde moitié du XVIIIe siècle," Annales. Économies, Sociétés, Civilisations 26, no. 1 (1971), 173-185.

37. "Lettre au Contrôleur Général sur l'abolition de la corvée pour le transport des équipages," April 19, 1765, in OT, 2: 428; D'Hugues, Essai, 129-134, 155. 
principal manufacturing industry, in addition to paper, was military equipment, for French and foreign governments: "the cannons, bullets and bombs that are made in these provinces," as the consular judges of Angoulême wrote in 1772, appealing for "the freedom of commerce to the French islands in America and to the coasts of Guinea." 38

The long, intermittent war of the mid-eighteenth century, from 1740 to 1783 , was a universal conflict, in that it engaged a relatively high proportion of the French population; close to a million men who served in the armed forces, and many more who were part of the military economy. ${ }^{39}$ There were English prisoners of war in Angoulême in the Seven Years War and in Limoges in American Revolutionary War, with an attendant business of prison supplies; the castle of Angoulême was even the scene, in 1759, of a notarized "visitte du pain," or an inspection of the excessively brown and soggy bread provided to English naval prisoners, under a subcontract from the lieutenant of the navy in the port of Rochefort. ${ }^{40}$

There were also the services that the state extracted from its subjects. The militia, with its terrible "tirage au sort," or lottery, inspired Turgot to one of his great political romances. Young men were forced to "expose themselves to a destiny the very idea of which plunges them into despair," he wrote to the minister of war in 1773, in support of a volunteer militia; and "there is nothing which makes the people feel more strongly their degradation and their servitude." There was a "continual emigration" away from the affected parishes, with the fugitives condemned to lead "a life which is always anxious [inquiète], always agitated."41

38. Arnould, De la balance du commerce, 3: Table 8; Huet, Dubois, Jeudy, Marchais and Clavaud, $A U R O I$ (n.p., n.d. [1772]), 2, 4, n.(a). The principal business of the forges was "great guns, bombs, and bullets"; [Jacques Savary des Brûlons and Philemon-Louis Savary], "Angoumois and Limosin," The Universal Dictionary of Trade and Commerce, 4th. ed., 2 vols. (London, 1774), 1: n.p.

39. Riley, The Seven Years War, 77-79.

40. "Procès verbal et visitte de pain," October 26, 1757 ADC, Caillaud, notary, 2E266.

41. The first criminal procedure Turgot had to comment on in the generality concerned a dispute over the militia in two tiny interior parishes, a murder, the local "syndic" or mayor, who had 
The lottery for the militia was surrounded, in turn, by a larger circulation of information; the "multiplier effect" of a public procedure. ${ }^{42}$ For every young man selected, in France as a whole in the late eighteenth century, another twenty were inscribed in the lottery, one was a fugitive, and a further eighty had been exempted because they were too short, or the servants of noblemen, or employed in protected occupations. ${ }^{43}$ The two lotteries for the militia in Angoulême in the war-time year of 1758 provide a vivid sense of the world of anxiety which surrounded the prospect of enlistment. 33 soldiers were selected; 177 were listed as absent, and deemed deserters; an additional 33 of the inhabitants were selected to "contribute" to the costs of marching the new militia from Angoulême to Limoges. The "boys" selected ranged from a stone cutter of 14 to a glassmaker of 36 (who measured "five foot two inches, wearing a wig"); one of those rejected was a wigmaker aged 14 1/2 ("lame") and another, a pot-maker, was found to be aged "9 years and 9 months."44

Spain." "Lettre au ministre de la guerre," January 8, 1773, "Lettre au Chancelier," January 30, 1774, in OT, 3: 600-601, 606-607, 656-660.

42. On the "multiplier effect" in the economists' sense of "projects which directly increase the income of workers and start a round of expenditures (multiplier effect) throughout the economy," see Alvin H. Hansen, "Keynes and the General Theory," The Review of Economics and Statistics 28, no. 4 (Nov., 1946): 182-187, 186. The effect suggested here is of the information and expectations that surrounded individuals who were (actually or potentially) involved in longdistance exchanges, and that were multiplied throughout the economy, or the society.

43. On the pattern of exemptions over the course of the century, see André Corvisier, L'armée française de la fin du XVIIe siècle au ministère de Choiseul: Le soldat, 2 vols. (Paris, 1964), 1:197-222.

44. The boys who drew the tickets marked with an "M" were given permission to "search for and arrest the absentees," and to present the fugitives to serve in their place; they were permitted to use force, while observing "good order in all cases." 15 out of the 33 boys selected in the two lotteries of 1758 found and captured fugitives to replace them; immigrants to the town, for the most part. AM-A, EE5, "Etat des miliciens," "Etat des garçons fugitifs," February 24, February 26, October 4, October 91758. 
The economic life of the province was different, again, from the perspective of the family or the household; the even older perspective of the domestic economy. Outside events impinged on families in the generality of Limoges, above all, because of the commodity which even poor families did supply, or their own labor. The (extended) household was a location of the exchange of information and credit; and of the "bequests" and "inter vivos gifts," or the expectations about bequests, that have fitted only uneasily into evaluations of the economy as a flow of goods and services. $^{45}$

The generality was known as a place that people abandoned. "Several thousands of them leave it every year," in a contemporary description; "this is to them instead of trade, and by which other provinces grow rich." ${ }^{46}$ When Turgot first arrived, the inhabitants of a tiny interior commune wrote to him that "Every year, monseigneur, a prodigious quantity of people leave most of our parishes, who abandon their native country, from which misery drives them." They were oppressed by "the bailiffs of the taille, who commit a hundred military executions against these miserable individuals, and whom one can describe as true harpies:" "Spain, for example, takes away many people from us; the others go as masons, roofers, wood cutters, to various provinces of the kingdom. They bring some money, it is said, on their return: out of ten of these workers or these voyagers who leave, there are not two who succeed: illnesses, voyages, libertinage consume them all."17

45. Thomas Piketty, "On the long-run evolution of inheritance: France 1820-2050," Quarterly Journal of Economics 126, no. 3 (2011): 1071-1131; Franco Modigliani, "Life Cycle, Individual Thrift, and the Wealth of Nations," The American Economic Review 76, no. 3 (1986): 297-313.

46. Savary and Savary, "Angoumois and Limosin," n.p.

47. "Mémoire des habitans de Saint-Pardoux-la-Croisille" of September 19, 1762, in ADH-V, C. 102. Of a group of thirty-eight parish priests to the north of Limoges, surveyed in 1785, twentyfour complained of "emigrations" and the scarcity of labor; of peasants who were driven by taxes to "transmigrate to Bordeaux," or who go "on the roads," "in the hope of being treated more favorably under a foreign sky;" "the principal resource is to go away." "État par Paroisses de la Vicomté de Rochechouart en 1785," ed. Pierre Granet, in Archives Historiques du Limousin 4 (1892): 138-165 and 5 (1893): 238-294. 
The Limousin was a region of migration within France, and across the Pyrenees; the Angoumois, in the west of the generality, was one of the regions of traditional migration to the overseas colonies. But to leave was to be connected to the outside world. ${ }^{48}$ Migration transformed the perspectives of the individuals who left; and the little enclosed societies of the generality were transformed, in turn, by the migrants who returned, or who did not return, or whose return was imagined, longed for, or feared. ${ }^{49}$ "Where does it end, this region of the Limousin," Marc Bloch asked, in one of the notes that he published under the pseudonym "M. Fougères," while he was in hiding during World War Two; "by which I mean, if one wants to take account of the human connections which are truly living and clearly experienced." ${ }^{50}$

The most elaborate connections to the outside world, as in relation to the consumption of pink taffeta and Indian satin, were from the milieu of the provincial bourgeoisie and nobility. A little boy of eight, whose father had died in Canada and whose mother and grandmother had died in the colonization of Cayenne of 1763-1765, was the subject of two successive cases, involving five

48. The word "limosin," like "limosinage" and "limosinerie," was used of the construction workers "who spread across all the workplaces of the provinces, and particularly of Paris." Dictionnaire domestique portatif, 3 vols. (Paris, 1764), 2: 552. In Gabriel Debien's study of seventeenth- and early-eighteenth-century emigration to the colonies from La Rochelle, the Angoumois, together with Aunis, Saintonge, and Poitou, was the principal source of the "engagés" or indentured labourers for the colonies; the Limousin was a minor source of direct migration. Debien, Les engagés pour les Antilles, 99, 104, 113, 115.

49. As Alain Corbin wrote of the Limousin in the nineteenth century, "migration enlarged the horizon and the vision of society of the individual who practiced it." Corbin, Archaïsme et modernité, 222, and see Annie Moulin, Les maçons de la Creuse: les origines du mouvement (Clermont-Ferrand, 1997), 248-293.

50. Bloch, who lived near Guéret in the Creuse, wrote of the "practice of a curiously specialised emigration" that it was "perhaps the most striking characteristic of the past of the Limousin; the one, in any case, which best explains the impossibility in which this regional society has always found itself in identifying more or less stable outlines." The "vocabulary of the masons" was essential, in this respect, to understanding the "'notion' of the Limousin." M. Fougères [Marc Bloch], "Points de vue sur le Limousin," Mélanges d'histoire sociale 2 (1942): 77-81, 80. 
of his relatives, before the notaries of Angoulême. ${ }^{51}$ "I am very sad for our poor Limousin," one of Turgot's local acquaintances wrote to him on the day he left office to become a minister, in 1774; and went on to request a military honor, the Cross of Saint-Louis, for her son's father-in-law, a proprietor in Guadeloupe with "eight or nine hundred negroes." ${ }^{52}$

But there were other connections, as well, within the extended families of the times. As in the lottery for the militia, there was a multiplier effect of emigration, in relation to expectations of return, information about the lives of distant relatives, and the possibility of even modest inheritance. A wigmaker from Angoulême died in Cayenne; his brother and brothers-in-law, a saucepan-maker, a blacksmith, and a merchant living in Bordeaux, appeared before the notaries in 1772 to "farm," for 50 livres, his property, which consisted in the "privilege" of exercising the trade of barber in the town. ${ }^{53}$ A different case in the town, also in 1772, involved a dancing master, his brother-in-law, a wig-maker in Berlin, his son who was a surgeon on a plantation in Artibonite in Saint-Domingue (the modern Haiti), and a disputed inheritance; the eventual proceeds amounted to

51. Jean Charles de Montalembert later became a soldier in the colonies, fought for the British against Toussaint Louverture during the Haitian revolution, and died in Trinidad. Biographie universelle, ancienne et moderne, 85 vols. (Paris, 1811-62), 74: 223. The case before the notaries concerned a "packet containing letters of exchange," the "succession of his late mother and grandmother," which had been sent from Cayenne to the "store keeper of the navy" in Rochefort. Even the record of his birth, in Louisbourg, had been "deposited with the archives of the colony," in the "general warehouse of the colonies in the port of Rochefort." AM-A, parish register of St Martial, GG110/8-9. "Quittance de 4542 1. Donné par M. et Mad. Delaplace Delatourgarnier à M. Delavallière," September 6, 1765, ADC, Caillaud, notary, 2E282; "Avis des parents du fils mineur," November 23, 1766, ADC, Caillaud, notary, $2 \mathrm{E} 285$.

52. Letter of July 22 [1774] from Malezieu de St Chaman, Bibliothèque de l'Institut, Paris, Manuscrits de Condorcet, 19/866/15. The letter was apparently given to Condorcet, and never passed on to Turgot. Louise-Charlotte de Malezieu, was the mother of Condorcet's friend Mme. de Meulan, and the grandmother of Pauline Guizot. See Lettres inédites de Mademoiselle de Lespinasse à Condorcet, ed. Charles Henry (Paris, 1887), 43, n.1. Condorcet transmitted a muted version of her request to Turgot, with no mention of the son's father-in-law's slaves. Letter of August 1774 from Condorcet to Turgot, in Correspondance inédite de Condorcet et de Turgot 1770-1779, ed. Charles Henry (Paris, 1883), 187-188.

53. “Ferme de privillege de perruquier, ” June 16, 1772, ADC, Caillaud, notary, 2E295. 
7 livres, 14 sols, 3 deniers per person. ${ }^{54}$

It is these connections to the outside world that can be seen in closer perspective on the basis of the traditional sources of social history. Exchanges of information and "personal influence" are elusive, in what can be thought of as an information society, but at the opposite extreme of recordedness - to use a fanciful comparison - from the information society of our own times. They were opportunities for conversation -- the word "information," in eighteenth-century Angoulême, had the legal sense of a statement made in a judicial procedure -- and for the exchange of reports, knowledge and news, false or true. ${ }^{55}$ But it is these exchanges, or occasions for exchange, that are
\end{abstract}

54. The son on the plantation in Saint-Domingue was sensible enough to decline to send a power of attorney, on the grounds that it would cost more than the inheritance was worth; "Je ne puis vous Envoyer ma procuration atandu que Sela me couteroit plus que La Sucsaitions ne vos, jay parlé à un notaire Pour cela il m'a de madé soix ante douze livres." Letter from Louis Gabriel | Latour in Saint-Domingue to Marc-René Lefort Latour in Angoulême, August 8, 1772, ADC, Caillaud, notary, 2E296.

55. The comparison is between a world (our own), in which almost all conversations are by text or telephone or Facebook page, and almost everything one sees is seen on a screen or a lens; in which even the tiniest exchanges, in consequence, either could be or are recorded. Nothing, or almost nothing, was recorded, in the economic life of the eighteenth-century French provinces. But the (oral) exchanges of information or misinformation were a continuing preoccupation of contemporary observers. On the "swarm of triflers [who] buz in a market," see Arthur Young, Travels, During The Years 1787, 1788, and 1789 (Bury St. Edmunds, 1792), 75; on the multiple occasions for exchange, "conversation" and "distraction" within the agrarian life of the ancien régime, see Georges Lefebvre, "Les foules révolutionnaires" (1934), repr. in Lefebvre, La grande peur de 1789 (Paris, 1988), 247-253. On the "information" made, or laid, by a hatmaker, Michel Albert, in the criminal jurisdiction of Angoulême in respect of accusations of atrocious injury, see "Information faitte," July 17, 1769, ADC, 1B1090/2. On Paris as an information society, see Robert Darnton, "An Early Information Society: News and the Media in Eighteenth-Century Paris," American Historical Review 105, no. 1 (February 2000): 1-35, 7; on "long-distance information" in early modern Venice, see Filippo De Vivo, Information \& Communication in Venice: Rethinking Early Modern Politics (Oxford, 2007). 
so abundant in the extraordinarily rich parish, communal and notarial records which have been the materials of quantitative social and demographic history. ${ }^{56}$ The records are "structurally numerical," in François Furet's description; they can also be seen as structurally narrative. ${ }^{57}$ They are not transcriptions of exchanges about Cayenne or Berlin; how could they be? But they are records of the occasions for exchange, of which it can be said with more or less probability that they were also occasions for exchanging information and opinions about the outside world.

The long affair of the capitalists of Angoulême can provide one view of these long-distance connections. ${ }^{58}$ It began in 1769 , when a group of over-extended debtors in the town invoked longignored prohibitions on usury to demand restitution from their creditors. The creditors, who described themselves as "capitalistes," were eventually vindicated in 1776. But while one of the

56. The parish registers used in this article are the record of the events in the lives of Catholics, in the town where Jean Calvin wrote his Psychopannychia, "the sleep of the soul," and where one section of a register, for 1731-1735, was wrapped in a parchment, dated 1680, enjoining the mothers, fathers and masters of the town to restrain their children and servants from throwing mud and stones at persons of "the supposed reformed religion." AM-A, St Anthonin, GG52; the digitized record, including the parchment, is available at http://www.angouleme.fr/archives/ views 164-165, 178-179. On the riches and difficulties of parish registers, see Pierre Goubert, "Une richesse historique en cours d'exploitation: Les registres paroissiaux," Annales. Histoire, Sciences Sociales 9, no. 1 (Jan. - Mar., 1954): 83-93.

57. François Furet, “Quantitative History,” Daedalus 100, no. 1 (Winter, 1971): 151-167, 158.

58. The affair of the usurers was discussed in detail in E. Munier, Essai d'une méthode générale propre à étendre les connoissances des voyageurs (Paris, 1779), 265-272, in M.J.A.N. Condorcet, Vie de M. Turgot (London, 1786), 53-56, and in a memoir by Turgot, written before 1772, and published in 1789; A.R.J. Turgot, Mémoires sur le prêt a intérêt et sur le commerce des fers (Paris, 1789). On the early stage of the affair, see Emma Rothschild, "An Alarming Commercial Crisis in 18th Century Angoulême: Sentiments in Economic History," Economic History Review 51, no. 2 (May 1998): 268-293. The later stage, involving the taille office, became "the affair" of "all the receivers of royal revenues in the entire extent of the kingdom." It was described as an "extraordinary affair" which had made "an astonishing noise," and it was invoked, almost a century later, as a pure instance of the legal system of the old regime, "complicated, arbitrary, almost barbaric." Mémoire à consulter et consultation pour les sieurs Marot (Paris, 1784), 67, Correspondance secrète, politique \& littéraire, 18 vols. (London, 178790), 17: 312 and "Requêtes de l'hôtel du roi au souverain," Gazette des tribunaux 27, no. 8 (1789): 116-122, and see Jules Simon, La liberté, 2 vols. (Paris, 1859), 1: 175-176. 
creditors - he was the receiver of the taille -- was in Paris in connection with the case, an assistant clerk in his tax office began to steal small sums of money; or so the creditor alleged. In 1778, the young clerk was charged with theft and falsification of registers; he in turn charged the tax official with unjust imprisonment, in his house, which was also the tax office. The lawyers who were involved in the earlier affair re-emerged; the inner rituals of tax collection were described in excruciating detail; the clerk was twice sentenced to death, and once hanged in effigy; the affair ended in 1789 with the vindication of the clerk. ${ }^{59}$

The affair was a celebrated instance, at the time, of the isolation and introspection of the French provinces. The creditors represented the new, modern economy of capital and exchange; the debtors were figures from the insecure world of government contracts. In the continuation of the story, the receiver of the taille became the embodiment of the arbitrary power of government officials. ${ }^{60}$ But the affair was also a story of exchanges with the outside world, in the information society of the times. One of the creditors, a paper merchant called Abraham Robin, wrote his own "secret history" of the "revolution that took place in the commerce of Angoulême," and it is a story that is intricately connected with overseas events. ${ }^{61}$

The crisis began, in Robin's account, with the "long war of 1740" (the War of the Austrian

59. "Requêtes de l'hôtel du roi au souverain," [François Laplanche], Doutes, réflexions et résultats sur l'accusation en crime de vol, intentée par le sieur Marot (Paris, 1785). A transcription of the many complaints in the case is in AN, Requêtes de l'Hôtel, V/4/1485A1493B (1778-1784); there are also eighteen notebooks concerned with the complaint of unjust imprisonment in ADC, 1B1099/2, November 17, 1778.

60. Angoulême was a town which should have been "commercial," Turgot wrote in his memorandum about the early phase of the affair, but which was not; in which entrepreneurs preferred to seek advantage by buying positions, becoming part of the petty nobility, and seeking to profit from government contracts. "Mémoire sur les prêts d'argent," in $O T, 3: 156-157$.

61. Abraham-François Robin, "Recueil Secret des pièces utiles et intéressantes concernant la Révolution Arrivée dans le Commerce de Banque de la Ville d'Angoulême, et les Persécutions Suscitées aux Banquiers en 1769," ADC, Fonds Mazière, item J607. A transcription of the "Receuil" was published in 1919, and all references are to the published version, except as noted. Robin, "Recueil Secret," ed. Abbé Mazière, Bulletins et mémoires de la société archéologique et historique de la Charente [hereafter BSAHC], ser. 8, vol. 9 (1919): 3-76. 
Succession), and the interruption of commerce in the province. It was precipitated in 1759 , when "the government, exhausted by a ruinous war," suspended payment on its debts to the arms suppliers. The debtors, who Robin described as the cabal, "spread in the public places and squares of Angoulême, in the neighbouring towns and the countryside, libels and songs, where each of the bankers was named with the most atrocious epithets," Robin wrote; their object, another creditor complained, was to spread, in "muffled voices," their "clamors" and their false "sounds." 62

There were thirty-six debtors or "cabalistes," according to Robin's history, and five "capitalistes," who were eventually the successful plaintiffs in the king's council. ${ }^{63}$ The cabalistes were from the periphery of long-distance commerce. They had taken out risky loans; they were dependent on government contracts. One of the leaders of the cabal was a "supplier of artillery" to the military, from a village in the Dordogne; another was a forgemaster; a third was also a forgemaster, and a supplier of cannons to the French and Spanish armies. He "died bankrupt and destitute," in Robin's retrospect; he assured his creditors, shortly before his death in 1772, that "the ministers of the navy of both Spain and France have given me great hopes" that he would soon be repaid the 120,000 livres that he was owed by Spain; his nephew, a year later, lamented that there were "92 cannons" in Cadiz, and "three mortars [which] are in the mud and all rusted." ${ }^{, 64}$ Another member of the cabal, a merchant, was married to the sister of a bankrupt brandy merchant; he too, by 1773 , was "bankrupt and exiled to Martinique."

62. Robin, "Recueil Secret," 26; "Sommation faitte par M. Marot, receveur des tailles," November 23, 1771, ADC, Caillaud, notary, 2E294.

63. Robin, "Recueil Secret," ADC, J607, 53-56. The printed transcription omits the names of two of the cabalistes; Robin, "Recueil Secret," 41-43.

64. Robin, "Recueil Secret," 42, 54. Letters of Blanchard de Sainte-Catherine of April 25, 1772, and of Marvaud du Brandeau of April 23, 1773, in Abbé Mazière, "Appendix," in Robin, "Recueil Secret," 71, 75.

65. "Procuration donnée par le sieur Pechillon de la Bordrie," May 1, 1773, "Vente faitte à la demoiselle Marchais, épouse dudit Sr Pechillon," June 13, 1773, ADC, Caillaud, notary, 2E297; Robin, "Recueil Secret," 42. 
The least opulent of the cabalistes was a saddlemaker, who had been involved in a dispute in 1766 with the naval intendant of Angoulême, in the river port of L'Houmeau, over two cabriolets or carriages, which had been rented to the "inspector of the navy to take him to Nantes." He had complained, in 1762, about having soldiers billeted on him for two consecutive nights. ${ }^{66} \mathrm{He}$ was also, like so many others in Angoulême, connected by family relationships to the French colonies. In the midst of the usury crisis, he appeared before the notaries of Angoulême to deposit a letter from his brother in Saint-Domingue; about their parents' inheritance and the generosity (or otherwise) of their other brothers, and to report that "two thirds of this island are already in great trouble," with only a small chance "of avoiding a civil war."67

The "capitalistes" or creditors were by contrast, in Robin's description, "the most respectable people in the town, who had taken on honourable offices and enjoyed the highest reputation." Robin identified them by their public offices: alderman, judge in the consular courts, receiver of the taille, peer of the town, grand judge of merchants. ${ }^{68}$ They sold respectable commodities; silk and paper and printing services. But they, too, can be seen, from the perspective of the household economy, as intimately connected to overseas events.

Abraham Robin himself was the most sedate of the capitalists. He was a printer, with the contract for printing tax forms in Angoulême and neighboring towns; he was also secretary of the diocese of Angoulême. But he was involved, through his extended family, in distant events. His son Félix became a member of the sovereign council of Port-au-Prince in Saint-Domingue, and died there in 1792; one of his cousins, and namesake, emigrated to the West Indian island of St Vincent. Abraham Robin's oldest son, Léonard, was the lawyer and eventually the heir, in Paris, of an opulent and partly blind musketeer called Méhémet-Aly, born in Alaşehir (Philadelphia) in Asia

66. "Procès-verbal de deux cabriolets," July 22, 1766, ADC, Bernard, notary, 2E156. "Logements des troupes," letter of December 28, 1762, from M. de Boisbedeuil to the mayor of Angoulême, AM-A, Correspondance des intendants, AA17.

67. "Depost d'une lettre missive par le Sr. Dumergue aîné," letter of February 2, 1769 from François Dumergue in Fort Dauphin, May 31, 1770, ADC, Caillaud, notary, 2E291.

68. Robin, "Recueil Secret," 23-25, 45. 
Minor. $^{69}$

Two of the other leading capitalists were father and son. They were former silk merchants and changers of money for the king, and their long-distance connections were far more elaborate. One was the father-in-law, and agent, of a local man, "Cazeau de Roumillac," whose family had lived in Guadeloupe (listed variously as "La garde Louppe" or "Gouadeloupe" in the parish records), and who emigrated to Grenada in $1753 .{ }^{70}$ When the island of Grenada was ceded to the British in 1763, Cazeau appeared as a proprietor with 50 "negroes paying tax;" in 1770, he was imprisoned "in the same gaol with the run-away negroes and malefactors of every class," for the crime of reading aloud in French "in a tumultuous manner." ${ }^{71}$ In 1779, he was the defendant in a dramatic lawsuit in which Jean-Alexandre James, an "African from the kingdom of Timor," who had been sold into slavery in Grenada, sued for his freedom in French Admiralty Court, charging

69. The younger Abraham François Robin, "former surgeon-major of the island of St Vincent," married an English woman, and returned to Angoulême, where he died at the age of 82, having retired as "receiver of indirect taxes." AM-A, Petit Saint-Cybard [hereafter PSC], GG68/95; état civil, 1E102/7. On the death of Félix-Léonard Robin in Saint-Domingue, see M.J.Dupin, "Notices sur Abraham François Robin, premier échevin de la ville d'Angoulême et Léonard Robin son fils, membre du tribunat," BSAHC, ser. 4, vol. 6, pt. 2 (1868-1869): 825-906, 901. The legacy to Léonard Robin, Abraham Robin's oldest son, from Méhémet-Aly, who had converted to Christianity in 1751 under the name Jean-Marie-Alix Boullon Morange, was later contested in a bitter suit by another Parisian of Turkish origin, Charles-Marie Canalès-Oglou. Canalès-Oglou alleged that he too was a distinguished Turk, born in Smyrna, who had converted to Christianity, and was the first cousin of Méhémet-Aly/Boullon Morange. The case, in 1806, turned on the deathbed testimony of a lemonade maker and the practice of public records in the Ottoman Empire. Réclamations pour le sieur Charles-Marie Canalès-Oglou (Paris, 1806), 11-12, 21-22, 49-60, 66; Philippe Antoine Merlin, Répertoire universel et raisonné de jurisprudence, 3rd ed., vol. 3 (Paris, 1807), 69-73.

70. "Marché d'engagement de Ferrand et Delorière à M. Cazeau de Roumillac," December 15, 1753, ADC, Caillaud, notary, 2E259. On Cazeau's family in Guadeloupe, see AM-A, St Jean, GG73/63 and GG74/70.

71. Census of Grenada, 1763, The National Archives, Kew (TNA), CO101/1/pt.1, f.25r; "Report presented to the Committee on February 20 1770," TNA, PC1/60/7; [Anon.], A Narrative of the Proceedings upon the Complaint against Governor Melvill (London, 1770), 108, 114. 
Cazeau and his daughter with atrocious and inhumane cruelty. ${ }^{72}$

The younger silk merchant, the brother-in-law of Cazeau, was related by his own marriage to the tumult of the Atlantic colonies. His sister-in-law was the heiress from Martinique with the 124 shirts. ${ }^{73} \mathrm{He}$ and his wife were themselves parties in a legal case of mind-blowing complexity, involving 21 members of the family of a merchant hatmaker, and the disputed inheritance of an uncle who had emigrated to Martinique, and returned home to die. He was also involved, without leaving Angoulême, in the social relationships of slavery. In 1758, the bishop of Angoulême presided over the baptism, in the parish church of St André, of a "naigre [a negro] nation de Capélaou de la guisnée," aged about 15. The boy was named "Claude," and his godfather was the younger capitalist/silk merchant; "to whom he belongs."74

The fourth of the capitalists was a lawyer, and he was married to the first cousin of the owner of "Claude." He too was a party in the case of the disputed inheritance in Martinique, which turned on the proceeds of the sale of the uncle's slaves and currency (including a Venetian gold coin and four "pagodas," or Indian-Chinese coins.) There were also wartime obligations of 1758 , for the "extraordinary expenditure of the colonies," on which some coupons were payable only on the basis of a lottery, and others had been suspended; there was an elaborate accounting of the distinction between "capital, income, interest and sums advanced;" there were boxes of shells and cases of olives from Marseille, for which the lawyer/creditor's mother-in-law paid the freight and duty; an apprenticeship for a boy in Angoulême, the son of a wigmaker; and a debt, of 5,333 livres, that the

72. Mémoire pour Jean-Alexandre James, negre, Intimé. Contre le Sieur CAZEAU, Appellant de la Sentence de l'Amirauté (Paris, [1779]). Cazeau reappeared, in 1780, as "de Casaux," writing to the French ministry of the colonies from a hotel in Paris, and then as "le Marquis de Cazaud," writing to the British government from a hotel in Leicester Square, London. Letter of February 1, 1780, AN, correspondance colonies, Grenada, C10a/3/1; letter of May 17, 1790, TNA, CO101/30/61/f.309r-v.

73. "Inventaire des meubles de dame Gonnet," December 5-7, 1768, ADC, Caillaud, notary, 2E288.

\section{AM-A, St André, GG42/113.}


uncle owed to a woman known only as "Henriette mulatresse."75

Only one of the capitalists, the receiver of the taille who became the principal figure in the continuation of the affair, was unconnected by family relationships to the outside world. But the unfortunate clerk who was accused of theft and imprisoned in the tax office, the son of an innkeeper and son-in-law of a shoemaker, had his own long-distance connections. ${ }^{76}$ He had been attached as a young boy, he said in his defense, to a rich Englishman in Bordeaux, who had given him "a fine wardrobe, much money, and jewels." He too had a rich uncle (in Guadeloupe), who had sent him large sums of money. The case even turned, at one point, on whether the uncle was poor or rich; in the clerk's account, "my uncle had a large number of poor relations, who were burdening him with demands. To free himself of their importunities, he wrote me ostensible Letters, where he said that he was poor. He wrote to me in particular to show these letters to his other relations: but he was only poor for them; in relation to me, he was rich and benevolent.",77

Even the tax office was inhabited, after 1783, by a sojourner from distant parts, a former engineer for the Dutch East India Company in Bengal and expert on ditches in the French East India Company's colony of Chandernagore. The new tenant was the official in charge of water and forestry in Angoulême; his two daughters were described, when they died in Angoulême in 1849, as having been born in Pondicherry. He was also a litigant in the Chancery Court in London, in 1772, against two officials of the English East Company whom he believed to have cheated him out of the

75. Or rather, it was Henriette's own money, the proceeds of "a sum received on her behalf" from another merchant in Martinique, the father of the heiress with the 124 shirts. "Depost de testament de M. Tremeau," March 14, 1761, ADC, Caillaud, notary, 2E273; "Règlements et partage de partie des biens de la succession de feu Monsieur Trémeau Dupignon fait entre ses héritiers," May 10, 1768, ADC, Caillaud, notary, 2E287. The very last words, on the last page of the eventual settlement, were a fragment of an afterthought, on the part of one or other of the signatories; "and in like manner, the four boxes of shells."

76. Baptism of François Laplanche, AM-A, St Jacques, GG127/93, and of Susanne Basque, St Martial, GG108/6.

77. Doutes, réflexions et résultats, 65-68. On uncles from America and family inheritance in Navarre, see Pierre Force, "Stratégies matrimoniales et émigration vers l'Amérique au XVIIIe siècle," Annales. Histoire, Sciences Sociales 68, 1 (2013): 77-107. 
insurance on an ill-fated voyage carrying slaves to "the coast of Mallay, the streights of Malacca and Borneo."78

The history of Marie Aymard provides a view of the influence of the outside world in a very different setting of economic life. She was born in Angoulême in 1713, and died there in 1790. ${ }^{79}$ When the son-in-law of the silk merchant in the usury case left for Grenada in 1753, he took with him a joiner and a carpenter, who were "engaged" for a period of two years; Marie Aymard was the wife of the joiner. ${ }^{80}$ She could not write, but she had letters written for her, and sent to her husband in care of a merchant in Grenada. In 1764, she appeared before the notaries in Angoulême, to recount that her husband had some years earlier been able to buy "a certain quantity of negroes and some mules," had made a "small fortune," and had set off to return to his family. He earned 24 livres per day, and "his negroes brought him" a further 15 livres per day, she had heard. But he died in a charity hospital in Martinique on the way home, "after having left his fortune in the hands of M. Vandax a shipowner or merchant living on the harbour promenade of Martinique or in Fort St

78. The official was Claude Ogerdias, who assumed the office of master of water and forestry in Angoulême in July 1773; ADC, Registre des audiences de la maîtrise des eaux et forêts, July 19, 1773, B140/58. On his tenancy of the ill-fated tax office, see [Riffé de Caubray], Mémoire pour un homme condamné deux fois à la mort (Paris, 1788), 29. Ogerdias was a merchant and water engineer in the French and Dutch settlements in India. His trading ventures were listed in the course of litigation in the English Chancery Court in 1774; "Complaint of Claude Ogerdias," July 16, 1774, TNA, CO12/1014/9. His career in Chandernagore is described in F. Lequin, Het Personeel van de Verenigde Oost-Indische Compagnie in Azie in de Achttiende Eeuw (Leiden, 1982): 105, 137, 283. Deaths of Jeanne Françoise Ogerdias and Agathe Ogerdias, November 4, 1849 and November 13, 1849, AM-A, état civil, 1E151/88, 91. Agathe Ogerdias was in fact born and baptised in Angoulême in 1775; AM-A, St Jean, GG75/43.

79. Baptism of Marie Aymard, February 8, 1713, AM-A, St Anthonin, GG52/97; death of Marie Aymard, April 21, 1790, PSC, GG 68/117.

80. "Marché d'engagement," ADC, Caillaud, notary, 2E259. 
Pierre, these are the facts of which the deponent has been instructed at different times by certain people in the town of Angoulême." "This hope, her indigence, and the distance forced her to defer, until present, her researches," she said; she now, having heard that a sublieutenant in the merchant navy was going to Martinique, wished to nominate him, in a procuration or power of attorney, to recover the possible fortune; for which she pledged "all her goods and those of her said children." ${ }^{81}$

Marie Aymard was illiterate, as she declared to the notaries at the time. Her mother and father were also illiterate. Her father died when she was a young child; her stepfather was a carpenter. ${ }^{82}$ Her husband, Louis Ferrand, was described when they married as "a joiner's assistant. ${ }^{, 83}$ He came from a parish in the generality of Tours, some 200 kilometres to the north of Angoulême; he belonged, long before his engagement to go to Grenada, to the insecure world of itinerant carpenters and masons and roofers. ${ }^{84}$ Even in Angoulême, he and Marie Aymard lived itinerant lives. Their eight children, of whom six survived infancy, were baptised in four different parishes of the town, over a period of thirteen years; Marie Aymard was born in a fifth parish, moved again after her husband's death, and was buried in yet a different parish. ${ }^{85}$

The family lived at the edges of the enclosed economy of provincial trades and regulated guilds. They belonged to the "people," although not to the "poor," and their economic lives were insecure. There is a record, very unusually, of everything that Marie Aymard owned, or said that

81. "Procuration par Marie Aymard," ADC, Bernard, notary, 2E153.

82. Marriage of Pierre Aymard and Anne Queil, AM-A, St Anthonin, GG52/94; marriage of Gabriel Boisdon and Anne Queil, GG52/111.

83. Marriage of Louis Ferrand and Marie Aymard, AM-A, St Paul, GG89/20.

84. On the world of mobility in eighteenth-century France, see Roche, Humeurs vagabondes. Louis Ferrand was described in the record of his marriage as coming from Toussigny (Tauxigny) in the diocese of Tours; Tauxigny was a "bourg," with an estimated 270 households. Expilly, Dictionnaire géographique, 4: 340 .

85. AM-A, St Anthonin, GG52/97, St Paul, GG 89/20, 25; St Paul, GG89, 36r (page omitted from the online record); St Martial, GG106/116,151; PSC, GG67/18; St André, GG40/150,176, GG41/108; burial of Marie Aymard, cemetery of Notre Dame de Beaulieu, PSC, GG68/117. 
she owned. In 1760, her oldest son, Gabriel Ferrand, who was then 22, presented himself to one of the Angoulême notaries, and declared that he had established a home of his own. But "seeing his mother in a situation where she was no longer able to live, and to support herself without his help," and wishing to demonstrate to her, after the death of his father, that "his sentiments are to comfort her, as much as is in his power, and to make her life less harsh," he had entreated her to come and live with him. Marie Aymard, "wishing to profit from the good heart of her son," and "assuming that his benevolence towards her will continue, and that he will not abandon her to the lot in which a sad distress would place her," decided to accept his offer, and to move to his home. She brought her furniture with her, and it was described in the notarial document. There were two old wooden beds, garnished with very worn green serge; two half-cabinets or wardrobes; a "worn-out" square table with "ten old bad chairs;" twelve plates, six spoons of ordinary tin, six iron forks, and six sheets. The "two parties" - Marie Aymard and her son - agreed that the value of the property was 130 livres. $^{86}$

A little less than four years later, in 1764, Marie Aymard and her son appeared again, before a different notary in the town. The furniture and linen were enumerated once more. But Gabriel had been obliged, in the meantime, to make payments, "out of his own funds," to a number of creditors of his mother, who wanted to take action against her, and seize the "said furniture." She owed money to a shoemaker, a maker of potash for washing clothes, someone who sold cooking fat, and a cloth merchant, all represented by local lawyers; the total of her debts was 290 livres. Gabriel considered taking out an order against his mother, for the seizure and judicial sale of the furniture. But she had explained to him, as they recounted to the notaries, that the costs of a forced sale would consume almost the entire value of the furniture. She proposed that she sell it to him, "a la miable," or in a friendly manner; he bought everything from her, in 1763 , for 160 livres. $^{87}$

86. "Acte entre Aymard Ve Ferrand et Ferrand son fils," May 6, 1760, ADC, Jeheu, notary, $2 \mathrm{E} 850$.

87. "Vente de meubles par Marie Aymard à Gabriel Ferrand son fils," January 10, 1764, ADC, Bernard, notary, 2E153. 
Marie Aymard is an odd illustration, in these circumstances, of the multiplier effects of information and expectations about long-distance commerce. She was the illiterate and immobile daughter of illiterate parents. She described herself as living in "indigence," in the procuration of 1764. Her entire worldly wealth at the time can be valued, with unusual precision, as amounting to minus 130 livres. Her social relationships - or her social network - consisted of the more or less insecure tradespeople of Angoulême, the joiners and carpenters and tailors in her own family, the locksmiths and barrel-makers who were the godparents of her children, the shoemakers and washing powder sellers to whom she owed money. ${ }^{88}$

But Marie Aymard's procuration is also a remarkable description of her sources of information. There were "the facts" about which she had been "instructed." There were the people who had "reported" to her that the merchant on the promenade in Martinique, the supposed repository of her husband's fortune, had "replied obscurely to the inquiries which had been made verbally to him." There were the letters that she had "written for her." The procuration is a description, too, of her hopes and fears; or of a universe that is crowded with memories of the past, and expectations about the future. It was in 1753, she recounted, that her husband left for the islands; it was over the next four or five years that he made his "small fortune," and that she sent letters to him, addressed in care of the two individuals with whom he had formed a "particular acquaintance." He went to Martinique from Grenada, or so she had learned, "in the idea of leaving from there to return to his family." She understood, now, that she would in the future be unable to "subsist," or to take care of her children, without the help of her inheritance; it was this, and the imminent departure of the sublieutenant, which led her to take out the procuration. ${ }^{89}$

There is another, even more remarkable notarial record, again from 1764, which is a picture, in a literal sense, of the social world of Marie Aymard's information: of her social network. It is the

88. The godparents of Marie Aymard and Louis Ferrand's eight children for whom occupations were noted were a hatmaker, a carpenter, the wife of a barrel-maker, a locksmith, another locksmith, and the wife of a locksmith; see above, n. 84 .

89. "Procuration par Marie Aymard," ADC, Bernard, notary, 2E153. 
marriage contract of her oldest surviving daughter, Françoise, with Etienne Allemand, the son of a tailor in Angoulême. The contract was signed in her son's home, in December 1764, and the couple married a few weeks later. In the contract, they commit all their goods and rights, present and future; Françoise includes, explicitly, the goods which have come to her by the death of her father, "in whatever they might consist, and in whatever place they might be found," the goods "which might come to her in the future by the death of her mother," and a sum which she had lent earlier in the year to her brother and his wife, which she declared to be her own money, the "product of her industry and savings." 90

The most unusual part of the record is the conclusion. For the contract was signed by "the parties and their relatives who were present" (with the exception of Marie Aymard, "who declared that she did not know how to"). The signatures extend over two pages: the marriage contract was signed by 83 people. It is these 83 people who constituted the social network of Marie Aymard's extended family. They were present in the same house in Angoulême, on the same afternoon in December 1764, and they can all be thought of - if only by virtue of their presence there - as belonging to the world of individuals who had an interest in or information about outside and longdistance relationships, and in particular about the circumstances of the late Louis Ferrand, and his possible possessions in Martinique ("in whatever they might consist"). It was indeed this possibility of future fortune, or so one can presume, which was one of the explanations for the extraordinarily large number of signatories on the contract. ${ }^{91}$

But the 83 individuals provide a different sort of perspective, as well, on connections to the outside world in the generality of Limoges. Of the people who signed the marriage contract, there are 79 who can be identified, mostly on the basis of parish records. Of these, 32 were relatives of the bridegroom; a further 14 can be identified, on the basis of tax registers for 1763 and 1765, as close

90. "Contrat de marriage de Estienne Allemand et Françoize Ferrand," December 9, 1764, ADC, Bernard, notary, 2E153.

91. I have certainly never seen so many signatures on a marriage record, even one involving vastly richer families, in the notarial, departmental, or parish archives of Angoulême. 
neighbours of the father of the bridegroom, or of the brother of the bride. The signatories varied in age from 74 to 10.44 of them were women. Their occupations, or the occupations of their fathers and husbands, were mostly those of the small, sedentary guilds of the town: bakers, tailors, butchers and shoemakers; seamstresses; a button-maker; an oven-keeper; a wigmaker; a musician. There was

a master writer (the bride's brother); the two daughters of a commissioner of police; agoldsmith; a tax collector and his wife. There were a few local notables who signed, their names clustered together in two corners of the contract.

Only one of the 83 people who signed the contract actually went overseas, or outside France. Marie Aymard's youngest son, Jean-Baptiste, who signed his sister's marriage contract as a boy of 15, later made his own way to America. He married in Angoulême; his wife's uncle was the brother-in-law of the wigmaker who died in Cayenne. He and his wife emigrated to SaintDomingue, and returned to Angoulême as destitute refugees, where he was described in 1798 as a "watchmaker unable to work, because of weakness of sight, and having found employment at the depot for Portuguese prisoners, where he has not been paid for the past 18 months." 92

But there was a larger group of individuals who were connected, by their own networks of family or friendship, or by their involvement in the military economy, to distant and overseas events. $<$ FIG.1 NEAR HERE $>$ These relationships are depicted visually in figure 1, which shows the 83 signatories of the contract, together with other individuals who constituted their social networks in the town; "those close to them, relatives and friends," in the language of the parish clerks of Angoulême. ${ }^{93}$

The diffusion of information within social networks has been of interest, in particular, to historians of science; these "other individuals" in figure 1 can be described, in the spirit of the

92. "État des Refugiés, Déportés, et Propriétaires Colons, retirés dans le Département de la Charente, qui ont droit aux secours déterminés par la loi du 17 Frimaire, an 5," undated, ADC, L152.

93. On the language of relatives and friends, see AM-A, St André, GG45/128. 
history of mathematics, as having an "Aymard-Number" of $1 .{ }^{94}$ They are defined, here, as individuals having at least one of the following relationships to a signatory of the marriage contract of Marie Aymard's daughter: parent, child, sibling, spouse, or godparent-relation. ${ }^{95}$ They can be considered as the individuals who were the signatories" "primary conduits of information, opinions, and behaviors. ${ }^{96}$ Of the 304 individuals depicted in figure 1, the 83 signatories plus 221 other individuals related to them, 84 had a relationship (an Aymard number of 1 or less) to a person who was connected to the outside world.

The influence of the outside world - the probability that an individual had some sort of information or misformation about distant events - can thus be seen as it was diffused across social relationships. Individuals who travelled outside France are shaded deeply, in figure 1, and those with a family member who had lived outside France are shaded more lightly. The individuals who are palely shaded had one or more of the following connections: that they or a relative had been contractors to the army or navy; that they or a member of their household was selected in the lottery for the militia in Angoulême in 1758; or that they were immediate neighbours (inhabitants of the

94. On the "Erdös number," which measures the proximity of other mathematicians to the Hungarian mathematician Paul Erdös, defined as the co-authorship of scientific papers, see M. E. J. Newman, "The Structure of Scientific Collaboration," Proceedings of the National Academy of Sciences of the United States of America, 98, no. 2 (Jan. 16, 2001): 404-409.

95. A "godparent-relation" is defined here as a person who has one or more of the following relationships to a signatory of the marriage contract: godparent of, godchild of, godparent to the child of, co-godparent with. The source of the identification is in almost all cases the parish and état civil registers of Angoulême, available in or on the website of the AM-A; in the remaining cases it is the notarial records of the town, or other parish and état civil records available in the ADC. The nodes depicted in figure 1 represent individuals with an "Aymard-Number" of 1 . Linkages, or edges, between nodes are weighted according to the strength of the relationship between the two connected nodes. Nuclear family members, for instance, are linked with thicker edges and appear closer together on the graph than do godparents and godchildren. The graph was produced with the Gephi network mapping software. The data for the nodes and edges in figure 1 is available at http://www.fas.harvard.edu/ histecon/visualizing/angouleme/83.html

96. Benjamin Golub and Matthew O. Jackson, "Naïve Learning in Social Networks and the Wisdom of Crowds," American Economic Journal: Microeconomics 2, no. 1 (2010): 112-149, 112. 
same "island," or cluster of houses, as listed in the tax registers) as someone who lived outside France. $^{97}$

The saddler whose brother was in Saint-Domingue was thus one of the signatories, together with his wife. The dancing master with the brother-in-law in Berlin was the godfather of the son of two of the signatories. ${ }^{98}$ One signatory was married to the printer who supplied "passports and lodging passes" for the soldiers who passed through the town; another was his brother-in-law. ${ }^{99}$ The goddaughter of a signatory was married to a "writer to the navy" in the port of Rochefort. ${ }^{100}$ Four of the signatories were relatives of the bakers who had supplied the soggy bread to the English prisoners, in the case of the "visitte du pain." 101 The servant of a signatory, a butcher, was listed, in 1758, as a "fugitive from the militia." The brother-in-law of a signatory, a baker, was one of the seven men selected by lot, in the first drawing for the militia; he provided a substitute, a young immigrant to the town. The butcher with the fugitive servant was among the individuals who were required to contribute to the costs of the march of the newly conscripted militia, from Angoulême inland to Limoges; so was the widowed mother-in-law of another signatory, who was herself a

97. On the lotteries for the militia in 1758, see "Etat des miliciens," "Etat des garçons fugitifs," February 24-26, October 4-9, 1758, AM-A, carton EE5; on the division of the tax registers into "isles," see AM-A, "Cahiers de l'etat des classes," 1763, and "Répartition de la taille," 1765 , CC42 and CC62; on the definition of the "isle des maisons" in eighteenth-century town design, see M. Buchotte, Les règles du dessein et du lavis, pour les plans particuliers des ouvrages et des bâtiments (Paris, 1754), 36-37.

98. Baptism of Marc René Joubert, January 11, 1763, AM-A, St André, GG42/199.

99. Marriage of Rose Marin and Claude Rezé, August 11, 1764, AM-A, St Anthonin, GG54/5455; undated memorandum from Rezé, requesting an "augmentation of wages" from the mayor, on the grounds of increased costs in connection with "public ceremonies." AM-A, Milice, carton EE5.

100. Rose Rezé, the niece and goddaughter of the Rose Rezé who was a signatory, was married to Louis Bignon, described variously as "controller of the intendancy of the navy in Rochefort" and "writer to the navy." May 13, 1762 and May 22, 1763, AM-A, St André, GG42/188, 207.

101. "Procès verbal et visitte de pain," October 26, 1757. ADC, Caillaud, notary, 2E266. 
baker. $^{102}$

There were even conduits of information, within Angoulême, about the social relationships of slavery. Marie Aymard had been "instructed" about the slave economy, or the negroes that her late husband had bought, and the income that they "brought" him. Her youngest son, Jean-Baptiste, became the owner of "fifteen negroes" in Saint-Domingue, as he recalled many years later. ${ }^{103}$ The daughter of the saddler and his wife who were signatories of the marriage contract was married to a man named Louis Félix, who was born in Saint-Domingue and confirmed in Angoulême, the son of a French trader and an enslaved woman named Elizabeth. ${ }^{104}$ As early as 1733 , in the parish church of St André, with which 33 of the signatories were associated, there was a "great number" of spectators drawn by an unusual ceremony; it was the baptism of Jean-François-Auguste, a "negro of the nation of the coast of Juda," who had been brought "from the islands" by Jean-François Cazeau, the father of the Grenada proprietor; "he could be aged around 16 or 17."105 Claude, who belonged to the silk merchant in the affair of the capitalists, was baptised in St André in 1758. François Martin Aliquain, aged "around 12" and born in "laguinne en affrique," was baptised in 1775 in St Jean, after having "abjured paganism at the door of the parish church."106 Another signatory of the

102. "Etat des miliciens," "Etat des garçons fugitifs," AM-A, carton EE5.

103. Petition to the Minister of the Interior, received February 24, 1831, and petitions of December 18, 1822 to the Minister of the Interior and of October 24, 1824, to the new king, Charles X. AN, Secours aux réfugiés et colons spoliés, F/12/2795.

104. Baptism of "Louis Mulatre fils naturel d'un père inconnu et d'Elizabeth negresse esclave," November 1, 1765, parish register of Saint-Marc, Saint-Domingue, p. 45r, available at http://anom.archivesnationales.culture.gouv.fr/caomec2. Confirmation of Louis Félix, April 16, 1780, AM-A, PSC, GG68/81; marriage of Louis Félix, natural son of Jacques Orillac and Marie Elizabeth, and Marthe Dumergue, 29 fructidor VI (September 15, 1798), AM-A, état civil, 1E14/114-115.

105. The "young proselyte" wore a robe and carried a taper, showing a "devotion" which "delighted all the spectators." Baptism of Jean François Auguste, July 19, 1733, AM-A, St André, GG39/205.

106. AM-A, St André, September 3, 1758, GG42/113; baptism of François Martin Aliquain, St Jean, October 1, 1775, GG75/46. 
marriage contract, the daughter of a shoemaker, signed a different sort of record, also in 1775, in the parish church of Petit Saint-Cybard: the baptism of "Jean L'accajou," described as a negro, a native of Africa, aged 15, who had arrived in France on a ship called La Cigogne, and been duly "declared" at the Admiralty in La Rochelle. ${ }^{107}$

So what can be said, in conclusion, about the economic life of the interior of France and the influence or impact of the outside world? The history with which this article has been concerned is not economic history in the sense of an inquiry into "mass facts, of which there is a mass of evidence," and in which "everything that is important is repeated;" or "'big' history," suited to the macroeconomics of global transformation. ${ }^{108}$ It is not the story of "representative" or "characteristic" events (and the idea of a representative event is in any case dependent on the idea of a larger society, or a macroeconomy, that can itself be measured.) ${ }^{109}$ It is a history of people rather than of things (or prices.) But it is in the spirit of recent economic histories of early modern Europe, with their emphasis on the ways in which individuals in the past, including French peasants, were

107. Baptism of Jean L'accajou, September 3, 1775, AM-A, PSC, GG68/58.

108. Labrousse, La crise de l'économie française, 134, 171. On “'big"” history's engagement with economics and 'deep' history's with the sciences," see Kristin Mann, "Comment," in "AHR Conversation: How Size Matters," 1464. Economic historians, in Robert Allen's account, "seek the "causes"" of the wealth of nations "in a dynamic process of historical change," and "must ask why economic growth took off in Europe rather than Asia or Africa." Robert C. Allen, Global Economic History: A Very Short Introduction (Oxford, 2011), 1.

109. Françoise Ferrand was representative of the 96 women who were married in Angoulême in 1765 , to illustrate, in that she was aged 24; the average age was 25 . She signed her name, unlike 62 percent of the women. She married someone from the town; 36 percent of the women married husbands from parishes outside Angoulême. 12 of them were widows; 6 married soldiers. Three others had far more adventurous lives; one was the daughter of the commander of Port-au-Prince in Saint-Domingue, another married a colonel "in the service of Spain," and a third was the illiterate widow of a surgeon from the parish of St Marc, also in Saint-Domingue. AM-A, Notre Dame de Beaulieu, GG8/159, 161; St André, GG43/5-6. 
involved in markets, took risks, and made choices under constraints. ${ }^{110}$ It is in the spirit, too, of economic theories of information and of social networks, and of the microeconomics of development, with its openness to "many... kinds of evidence," qualitative and quantitative. ${ }^{111}$

It is in the spirit, most of all, of the profound assumption of the economists of the eighteenth-century enlightenment: that all individuals, without exception, are interested in improving their own circumstances, and that they are also inquisitive and discursive, living amidst elaborate relationships of employment, family, and friendship. Economic life, as A.R.J. Turgot wrote of the affair of the usurers in Angoulême, was a place of endless discussion, a "debate between every buyer and every seller," or an estimation of the "risk or the opinion of risk... which varies from one instant to the next." 112

So this has been an historical inquiry into the social connections of individuals in the past that has drawn, in part, on economic techniques and ideas. It is also a return to the new history of economic life that was the objective of the early Annales d'histoire économique et sociale; a history that had space for the evidence of what Marc Bloch - professor of economic history at the Sorbonne

110. As Naomi Lamoreaux has written of histories of the "agency" of "ordinary people," the discipline of economics is "founded on the idea that all individuals make choices under constraints." Lamoreaux, "Rethinking Microhistory," 559; and see Walter Johnson, "On Agency," Journal of Social History 37, no. 1 (Autumn, 2003): 113-124. On the "Caltech School" of early modern economic history, with its enterprise of demonstrating that individuals in the past, including French and other European peasants, were involved in markets and took risks, see Philip T. Hoffman and Jean-Laurent Rosenthal, "New Work in French Economic History," French Historical Studies 23, no. 3 (2000): 439-453; Sheilagh Ogilvie, "The Economic World of the Bohemian Serf: Economic Concepts, Preferences, and Constraints on the Estate of Friedland, 1583-1692," Economic History Review 54, no. 3 (2001): 430-453; and Tracy K. Dennison, "Did serfdom matter? Russian rural society, 1750-1860," Historical Research 79, no. 203 (February 2006): 74-89.

111. Banerjee and Duflo, Poor Economics, 15, and see Abhijit Banerjee, Arun G. Chandrasekhar, Esther Duflo, and Matthew O. Jackson, "The Diffusion of Microfinance," Science 341, no. 6144 (26 July 2013).

112. "Mémoire sur les prêts d'argent," "Lettre au Contrôleur Général," December 2, 1770, in OT, 3: 191, 326. 
from 1936 - described as "the reactions of human beings in the presence of economic facts, their sentiments of insecurity or of confidence, of anger or of satisfaction." ${ }^{113}$ It is inspired, in particular, by the "history of the economy" to which Bloch continued to return in his last writings; a probabilistic history, which was an effort to understand the lives of individuals in the past, and which was also, like all history, a history of "human consciousnesses." 114

The individuals with whom this history has been concerned lived at the periphery of the world of long-distance information, and of the written word. They had information which was almost certainly false (about the shipowner Vandax, for example, on the promenade in Martinique.) Their petitions and letters provide no more than the traces of individual lives. But they were surrounded by information. Marie Aymard had been instructed or informed about the "particular acquaintances" that her late husband had formed in the parish of "marquis du cabeste" in Grenada. The clerk in the affair of the taille had "ostensible letters" from his uncle. The brother of the saddlemaker wrote to him about the prospects for civil war in Saint-Domingue, and about the characters of their other brothers ("he has a good natural"). The dancing master's son wrote about acquaintances on the island ("he has just lost his son," or "her brother's plantation... would take five years to liquidate." $)^{115}$

The 83 signatures on the marriage contract of Marie Aymard's daughter are very difficult to make sense of in a calculus of (economic) interest. Even within a large extended family, it is

113. Georges Lefebvre, "Le mouvement des prix et les origines de la Révolution française," Annales d'histoire économique et sociale 9, no. 4 (1937): 138-170, 153, citing Marc Bloch's description of the documents which were missing in the work of the economic historian François Simiand.

114. Marc Bloch, Apologie pour l'histoire ou métier d'historien (Paris, 2007), 73, 115-121, 127 , 131.

115. "Procuration par Marie Aymard," ADC, Bernard, notary, 2E153; "Depost d'une lettre missive," ADC, Caillaud, notary, 2E291; letter from Louis Gabriel Latour in Saint-Domingue to | Marc-René Lefort Latour in Angoulême, August 8 1772, ADC, Caillaud, notary, 2E296. The "acquaintance" of her husband whom Marie Aymard mentioned, M. de Flavigné, was the proprietor of 167 negroes in the parish of Marquis, on the east coast of Grenada. Census of Grenada, 1763, TNA, CO101/1/pt.1, f.22v. 
unlikely that an eventual inheritance in Martinique would be divided with the step grandmother of the bridegroom. But the signatures are easier to understand in relation to interest in a different sense. The story of the inheritance was itself of interest, that is to say, or interesting. It was inquisitiveness, or the desire for information, that brought all these people to the home of Marie Aymard's son, on a December afternoon in 1764.

The history of eighteenth-century Angoulême has been an inquiry into a particular place and time. It is the story of events that really happened, in one of the interior provinces of France, that involved a relatively large number of people - the 41 cabalistes and capitalistes of Angoulême, and the 304 people who constituted the social network of the signatories of Marie Aymard's daughter's marriage contract -- and that were influenced by distant exchanges. It moves from a history of individuals, through an inquiry into the individuals' own relationships, to a larger meso- or macrohistory. It is "inductive" history, or a history "from the inside out," of a small, immobile society and its long-distance exchanges. ${ }^{116}$ It can be expanded, on the basis of the individuals' own connections; and to related investigations of changes over time. ${ }^{117}$ But it does suggest a change of perspective, in several respects, in relation to the familiar rhetoric of isolation in the deep or interior provinces.

"We are only poor peasants, living in a deserted and isolated location," the inhabitants of a parish outside Limoges lamented in 1789 , complaining about the endless snow; a parish to the north

116. AHR Editor, "Comment," and Mann, "Comment," in "AHR Conversation: How Size Matters," 1459, 1462, 1463.

117. The visualization of social networks used here starts with a group of individuals who were participants in a specific event in 1764; for a related visualization of all individuals who appear in the registers of the central parishes of Angoulême in 1764, see http://www.fas.harvard.edu/ histecon/visualizing/angouleme/networks.html 
of Angoulême described itself as a "sad image of the Arabian desert."118 This was the characteristic idiom of petitions to the intendant and to municipal authorities. ${ }^{119}$ But the reports and petitions were documents written to achieve a particular objective: a reduction in taxes, or an exemption from regulations, or an investment in new roads. The inhabitants of another parish near Limoges, in 1789, invoked the new world of long-distance connections, to complain of the "décroissances et bouffissures" (the comings-down and puffings-up) of the "public economy."120

The two Frances, of the obscure interior and the brilliant periphery, were connected, in the perspective suggested here, by domestic, public and economic exchanges. Angoulême, with its uncommercial "communities" or corporations, was at the limit of "La France profonde," in the twentieth-century sense of a stable, Catholic, industrious universe of small interior towns and villages. ${ }^{121}$ It was a world of continuing exchange between the countryside and towns, within a largely rural society. ${ }^{122}$ Of the 96 women who were married in the twelve parishes of Angoulême in

118. "Doléances de paysans limousins habitant une paroisse voisine d'Eymoutiers," in Archives révolutionnaires de la Haute-Vienne, Doléances paroissiales de 1789 (Limoges, 1889), 39; doléances of Agris, in Charles de Chancel, L'Angoumois en l'année 1789, ou Analyse des documents authentique (Angoulême, 1847), 362.

119. It was the idiom, in the generality of Limoges, of the parish priests who described the "execrable" state of the roads, or the inhabitants who complained about emigration to Spain, or of Turgot's own reports to the ministry of finance.

120. These were the inhabitants of Châlus, who described themselves as having populated "the ports [with] a brave and indefatigable race, by whom our communications and our glory are extended far and wide." "Cahiers des doléances et remontrances de la communauté de Châlus," in Doléances paroissiales de 1789, 3.

121. Marie Aymard's husband, before he left for Grenada, was a "syndic" of the community of joiners. "Menuisiers," 1744-1745, AM-A, HH5. On "La France religieuse, la France profonde," see Almanach catholique français pour 1920 (Paris, 1920), 428, and on the continuity over time of "la France profonde," Maurice Barrès, L'âme française et la guerre (Paris, 1919), 235.

122. In the generality of Limoges, the two principal towns of Limoges and Angoulême accounted for about 5 percent of the population. De l'administration des finances de la France, I, in Necker, Oeuvres complètes, 4: 325-327. On "le Limousin, le pays agricole par excellence," see Jean Loutchisky, La propriété paysanne en France à la veille de la révolution 
the same year as Marie Aymard's daughter, Françoise Ferrand, more than a third married husbands from outside the town, most of them from villages in the interior provinces of central France. Even the affair of the taille, in 1778, turned on a moment of distraction, and the arrival of a cattle merchant in the courtyard of the tax office, with some calves he was hoping to sell. ${ }^{123}$ The parish in which Françoise Ferrand was born was itself partly rural, extending outside the walls of the town to fields and quarries. It was a "rendezvous for all the victims of misery and indigence, not only from the province of Angoulême but from the neighbouring provinces," the inhabitants complained in 1782; "day-labourers, beggars, and the inhabitants of caves." 124

The change of perspective is also spatial or geographic. The iconic image of late eighteenthcentury France was of a nation that was drawn, as though by the force of gravity, towards the sea. ${ }^{125}$ It is a natural perspective for a largely Atlantic (or Mediterranean) transnational history. But the long-distance connections of individuals in the generality of Limoges suggest a different, and to some extent counter-intuitive picture, of information, money and credit moving inland, towards the interior of the country. The militia marched inland and up-river, from Angoulême to Limoges. Logs

(principalement en Limousin) (Paris, 1912), and on exchanges within rural life, see Lefebvre, "Les foules révolutionnaires." Lefebvre "constantly insists on the mobility of rural life, especially from the 1770s onwards," and "it is impossible even to make a clear division between town and country." R.C.Cobb, "Georges Lefebvre," Past and Present 18 (November, 1960): 52-67, 61.

123. Mémoire à consulter et consultation pour les Sieurs Marot (Paris, 1784), 24.

124. "Acte de delliberation des habitants de la parroisse St Martial de la ville d'Angoulême," September 1, 1782, ADC, Bernard, notary, 2E188. The only extensive study of the parish registers of Angoulême found that more than 30 percent of the population of St Martial, other than those living within the town walls, were "rural," mostly agricultural day laborers. Laurent Raynaud, "La population d'Angoulême au XVIIIe siècle (1700-1791): essai démographique" (University of Poitiers, unpubl. master's thesis, 1992), unpag., chapter 4.

125. This was the image of Joseph Vernet's port scenes, diffused in prints, porcelain flowerpots, and counterfeit paintings, and also of his two great inland vistas, of the construction of a road and bridge, and of traders making their way to a Mediterranean fair. See Gilles Grandjean, "Les Marchands Levantins, un décor inspiré par Claude-Joseph Vernet," in Autour de Claude-Joseph Vernet: La marine à voile de 1650 à 1890 (Rouen, 1999), 69-75; Coriat Junior, Another Traveller! (London, 1769), 140-141. 
for naval construction floated down to the sea, and news floated into the interior, borne by peddlers, naval inspectors, and the loggers and cattle-drivers who returned. Almost everything, in the inheritance cases in Angoulême, turned on the flux of information, people, and things towards the interior: the brother who came home to die, and the husband who died on the way home; the powers of attorney sent from Berlin and Saint-Domingue; "the facts" about which Marie Aymard had been "instructed, at different times, by various people in the town of Angoulême."

The microhistory of exchanges of information, like the history of the public and household economy, thus tends to confirm the observation, by so many economic historians of eighteenthcentury France, of a rapidly expanding long-distance commerce, connected in multiple respects to the interior economy. ${ }^{126}$ It is complementary, in this respect, to an economic history which starts with flows of commodities and the comparison of national economic indicators. It suggests different sources, in relation to individuals in their lives not only as people who produce (and consume) commodities, but also as subjects of the military-fiscal state, and as participants in exchanges within households or families. It also suggests different ways of using sources; in juxtaposing, for example, the sorts of individual histories that have been outlined here - in which the name is the "red thread" - with the quantitative history, also based on notarial records, of private credit in France. ${ }^{127}$

126. See Crouzet, "Angleterre et France," 265, Pierre Léon and Charles Carrière, "L'appel des marchés," in Histoire économique et sociale, ed. Ernest Labrousse, 4 vols. (Paris, 1970-1982), 2: 161-215, Louis Bergeron, "L'économie française sous le feu de la révolution politique et sociale," in Inerties et révolutions 1730-1840, ed. Bergeron (Paris, 1978), 347-368, and Pierre Léon, Marchands et spéculateurs dauphinois dans le monde antillais du XVIIIe siècle: les Dolle et les Raby (Grenoble, 1963). Daudin has suggested in recent work on the "heart of growth" that the economic importance of long-distance commerce was determined by its marginal as well as its average weight (or its share in increases in production), and by its weight in the overall use of new technologies, including "technologies" of information, exchange, and organization. Daudin, Commerce et prosperité, 397.

127. On the name as the red thread in the archives, see Carlo Ginzburg and Carlo Poni, "Il nome e il come: scambio ineguale e mercato storiografico," Quaderni Storici 40 (Jan.-Apr. 1979): 181190. On credit networks, see Philip T. Hoffman, Gilles Postel-Vinay and Jean-Laurent

Rosenthal, Des marchés sans prix: Une économie politique du crédit à Paris, 1660-1870 (Paris, 2001). 
The microhistory of Angoulême can even suggest a change of perspective in time. The "revolution in commerce" among the capitalistes of Angoulême unfolded, in the 1760s, amidst the changes that Tocqueville described in L'ancien régime et la revolution as the "first French revolution;" a time in which "each individual [was] anxious and agitated in his condition, and tries to change it," and when "'the French found only risks in their relationships with their own government." 128 This was a history, in Georges Lefebvre's description, of the "social influence of the economy," or of the "social consequences of economic change." ${ }^{129}$ It is also a history, in the perspective suggested here, of the influence of long-distance exchanges. It can be extended forward into the subsequent period of expansion in overseas exchanges (including in Angoulême.) ${ }^{130}$ It is continuous, too, with the larger fiscal-military economy of the revolutionary and Napoleonic period. ${ }^{131}$ This is no more, after all, than the space of a lifetime. Louis Félix, who was born in 1765

128. Tocqueville, L'ancien régime et la révolution, 271, 279. The onset of the "first" revolution was located, successively, in 1749-1759 ("about thirty or forty years before the Revolution broke out"), in 1769 (the government had become more active "since twenty years"), in 1774 ("the reign of Louis XVI"), and in 1774-1779 ("during the ten or fifteen years which preceded the French Revolution.") L'ancien régime, 269, 270, 274, 280; Fragments et notes, 33.

129. Georges Lefebvre, "Introduction," in Tocqueville, L'ancien régime et la révolution (Paris, 1952), 9-30, 21.

130. On the period between 1763 and 1789 as the most "brilliant" epoch of French colonization, see Jean Tarrade, "De l'apogée économique à l'effondrement du domaine colonial (1763-1830)," in Jean Meyer et al., Histoire de la France coloniale: Des origines à 1914, 2 vols. (Paris, 1991), 1: 199. In Angoulême, there were at least four other elaborate family histories of long-distance expectations, including the case of a widow from Saint-Domingue, living in temporary lodgings, who borrowed money from another sojourner from the island, to be repaid in three installments, respectively one year, two years and three years following "the peace of the present war." "Obligation de la somme de soixante dix mille livres par dame Marie Magdelaine Veyrier de Montaugé a M. Emery Chaloupin,” November 4, 1780, ADC, Bernard, notary, 2E184.

131. On the new historiography of the French revolution, see Paul Cheney et al., "La Révolution française à l'heure du global turn," Annales historiques de la Révolution française 374 (Oct.-Dec. 2013), 57-185; The French Revolution in Global Perspective, ed. Suzanne Desan, Lynn Hunt, and William Max Nelson (Ithaca and London, 2013), especially Lynn Hunt, "The Global Financial Origins of 1789," and Michael Kwass, "The Global Underground: Smuggling, Rebellion, and the Origins of the French Revolution." 
in Saint-Domingue to "Elizabeth, negro slave," freed at birth, and married the daughter of a saddler in Angoulême, became "commissioner of the executive directory" to the revolutionary "municipal administration;" he died in Angoulême, described as a "rentier," in 1851. ${ }^{132}$

The history of individual memory, and of memories of family life, is elusive; far more so than the national or collective memory which has been so prominent in the historiography of the French revolution. But it is difficult, in this same spirit - of a history of economic life that seeks to understand the events of individual as well as collective existence, and that has as its condition a shared foundation of human experience - to imagine that the exchanges with which this inquiry has been concerned were unimportant to the individuals involved; that they were exchanges without meaning. ${ }^{133}$

In the immediate family of Marie Aymard, at least, the influence - or the contagion -- of distant exchanges did endure, amidst the private memories of family life, into the generation of her children and grandchildren. Gabriel Ferrand, who lived in Angoulême throughout his life, and was described on his death in 1816 as "Head of the Bureau of Archives of the Prefecture of the Department of the Charente," received one of the earliest "certificates of civism" in the town, in 1793, together with three of his sons, of whom one was a captain in the revolutionary grenadiers; another son married into the extended family of a military officer in Martinique, and of the military governor of Cayenne. ${ }^{134}$ Jean-Baptiste Ferrand, in 1831, was living in Paris in "the most atrocious

132. Baptism of "Louis Mulatre," November 1, 1765, parish register of Saint-Marc, SaintDomingue, p. 45r; AM-A, 1E14/113-114, 1E157/89; on the revolution in Angoulême, see Jean Jézéquel, La Charente révolutionnaire 1789-1799 (Poitiers, 1992), 173-174, 224-226. On the continuity of French imperial and long-distance commerce, see David Todd, "A French Imperial Meridian, 1814-1870," Past and Present 210 (February, 2011), 155-186.

133. Bloch, Apologie pour l'histoire, 63.

134. Death of Gabriel Ferrand, December 20, 1816, AM-A, état civil, 1E52/426. "Certificats de civisme," "Certificats de residence," 1793, ADC, L146, L147. Etienne Ferrand married Marie Chausse Lunesse on 4 mess. II (June 22, 1794), AM-A, état civil, 1E2/124; her brother-in-law, Joseph de Bourgon, was a "former major in the regiment of Martinique," whose parents were the godparents, in 1775, of the 12-year boy who abjured paganism, and whose brother was military 
misery;" ineligible for compensation, as he wrote in a sequence of petitions to the commission that judged claims for property following the Haitian revolution, because despite the loss of his watch shop and his "fifteen negroes," and although he was considered "rather as a creole than as a European," he had been unable to prove that he was the proprietor of "even a corner of land." His daughter, the younger Françoise Ferrand, who was born in Angoulême in 1777, was herself a "refugee from Saint-Domingue;" in 1857, she was living in Paris in "unspeakable distress," supporting her granddaughters by embroidery, and her claims on the ministry of the navy. ${ }^{135}$

Martial Allemand Lavigerie, the oldest son of Françoise Ferrand and Etienne Allemand, was listed in his certificate of civism as "cuissier of tax receipts for the district." ${ }^{136}$ In 1790, he married the daughter of an apothecary, and they had a son, Léon-Philippe; in 1796, he and his wife divorced, and in 1801 he married the daughter of a plantation owner from Saint-Domingue, whose mother had died in the islands, and whose father died as a exile in Philadelphia. ${ }^{137}$ He then moved to Bayonne,

135. Jean-Baptiste Ferrand's petitions were well coordinated with political events. To Charles X, a month after his accession, he wrote "Already, Sire, hope has returned to my soul this goodness which marks the beginning of your reign by such generous actions that the Frenchman will never forget cannot be sterile only for me after having made so many people happy." To the government of the new July monarchy, and in the aftermath of the anti-royalist riots of February 1831 , he wrote "I am now 82, dying every day of privation, but at our regeneration a hope has taken hold of my entire being." His daughter, the younger Françoise Ferrand, supported her granddaughters by doing embroidery, with her eyesight failing "day by day." The last relief payment, in 1860, was after her death, and to her own daughter, in order to buy clothes so that she could find work. Petition to the Minister of the Interior, received February 24, 1831, and petitions of December 18, 1822 to the Minister of the Interior and of October 24, 1824, to the new king, Charles X; petitions to the Minister of Agriculture and Commerce of September 26, 1848 and November 9, 1857; petition of C. Brébion Ve. Collet of April 5, 1860; report of April 10, 1860. Dossiers "Ferrand," "Ferrand (Jn. Bte.)," and "Ferrand, Françoise, Ve. Brébion," AN, Secours aux réfugiés et colons spoliés, F/12/2795.

136. “Certificats de civisme,” ADC, L146.

137. Marriage of Martial Allemand Lavigerie and Louise Vaslin, April 13, 1790, birth of LéonPhilippe Allemand Lavigerie, 30 prair. III (June 18, 1795), divorce of Martial Allemand Lavigerie and Louise Vaslin, 2 brum. V (October 23, 1796), marriage of Martial Allemand Lavigerie and Marie Louise Bonite Raymond Saint Germain, 28 prair. IX (June 17, 1801); AMA, St André, GG47/64-65, état civil, 1E4/94, 1E11/4, 1E23/69-70. 
where he became "receiver of the lottery." His grandson by his first marriage, the great-great grandson of Marie Aymard, was Cardinal Charles Martial Allemand Lavigerie, Archbishop of Cathage, "Prelate of Africa," and the most prominent campaigner in France against the transSaharan slave trade. ${ }^{138}$ This family history, too, is part of the large story of the French provinces.

138. Martial Allemand Lavigerie was identified as receiver of the lottery in the death record of Louise Vaslin, February 18, 1823, AM-A, état civil, 1E71/17. On Cardinal Lavigerie, see Louis Baunard, Le Cardinal Lavigerie, 2 vols. (Paris, 1922) and Auguste Marie Michel, M.M., A mutilated life story: strange fragments of an autobiography (Chicago, 1911), 9-13, 21-22; letter of December 9, 1886, ADC, J1307. 
Notes 